\title{
The Effectiveness of Jarimatika Methods with Tapertis Media on Students' Multiplication Concept Understanding
}

\author{
*Kartika Yuni Purwanti, Ika Silfiana Arifatul Khoiriyah \\ Primary Teacher Education, Universitas Ngudi Waluyo, Jl. Diponegoro No. 186, Gedanganak, \\ Ungaran Timur, Semarang, Indonesia 50512 \\ *Corresponding Author e-mail: kartika.yuni92@gmail.com
}

Received: September 2020; Revised: November 2020; Published: November 2020

\begin{abstract}
The aim of this research was to prove the effectiveness of the use of Tapertis Media towards the 4 graders of Elementary Schools' multiplication concept understanding. The type of this research is experimental research. Using the intact-group comparison type of pre-experimental design. With 9 students as the sample of this research. Using purposive sampling technique. The methods used were the multiplication concept understanding test, observation, and documentation. Using validity of media expert, validity test, reliability test, normality test, homogeneity test, paired sample T-Test, and regression test for the data analysis. The result showed that Jarimatika with Tapertis media has effectiveness in improving the 4 graders elementary schools' multiplication concept understanding. The result of paired T-Test showed the significance level of $<0.05$ is $0.00<0.05$, then $\mathrm{Ha}$ is accepted. The result of T-test showed that the average of learning achievement of the experimental class was higher than the average of the learning achievement of the control class, and the significance level was $<0.05$, then $\mathrm{Ha}$ is accepted. The result of regression test showed that significance value of pre-reading skills is 0.038 where the value is less than 0.05 , therefore, the hypothesis is accepted. The data of the multiplication concept understanding value also showed that the learning average of the experimental class was greater than the control class. The data analysis result showed that Jarimatika with Tapertis media has effectiveness in improving the students' multiplication concept understanding.
\end{abstract}

Keywords: jarimatika; Tapertis; multiplication concept understanding

How to Cite: Purwanti, K., Y., \& Khoiriyah, I., S., A. (2020). The Effectiveness of Jarimatika Methods with Tapertis Media on Students' Multiplication Concept Understanding. Jurnal Penelitian dan Pengkajian Ilmu Pendidikan: e-Saintika, 4(3), 332-341. doi:https:/ / doi.org/10.36312/e-saintika.v4i3.267

\section{INTRODUCTION}

Learning mathematics requires a sufficient level of understanding so that with this understanding, the students not only memorize but also interpret what has been taught (Mei. et.al, 2020). Concept understanding is an advanced learning from inception that making the students have better understanding about concept (Heruman 2007). Concept understanding is a skill in understanding a concept, operation, and relation in mathematics. This is also explained that the students cannot understand a concept at school about the mathematics understanding before connecting between concept and understanding first (Zulal, 2015). Teachers in mathematics learning, are expected to give a chance for students to build the inception and concept understanding for them by themselves, so that they can create 
good vibes, active, and interesting in learning mathematics which has been considered as a difficult subject so far. In order to support the ability of mathematical concept understanding, meaningful learning is needed, where the students are required not to be passive and not to stop at the material given by the teachers, but as the subjects who are actively do the process of thinking, searching, processing, reducing, combining, concluding, and solving the problems (Purwanti, et. al, 2016). Students are said having a skill to understand the mathematical concept if they can do formulating the solving strategies, applying the simple calculations, using symbols to present the concepts, and changing one form to another such as fractions in mathematics learning (Mawaddah \& Maryanti, 2016).

Based on the observation about the multiplication concept understanding of the 4 graders of the state elementary school of Candigaron 03, Sumowono District, on multiplication material, the teacher only uses a whiteboard as the learning media. The teacher has given the example of how to count correctly, but the students' understanding of the multiplication concept is still low. The result of the multiplication concept understanding test showed an average value of 65,57, from the average value of the completeness percentages of 17 students, there are 10 students or $53 \%$ of the students who have not completed yet. The result showed that the students understanding about the multiplication concept is still low. From the interview result, it was also known that students difficulty in understanding the concept was caused by several factors, including the use of teacher-centered learning, the use of media was not optimal in the learning process, the lack of students concentration so it was difficult to focus on the lessons, only few students actively asked the questions and some of them were not interested enough in learning mathematics subject. Conventional learning focuses more on teachers and the students only tend to pay attention and accept the lessons, the students do not require to be active (Pratiwi, 2016). This is what makes the students difficult to complete the given tasks because they are not used to being trained with questions about concept understanding, it can be seen when the students solve the problem related to multiplication concept understanding, such as the students cannot connect the multiplication concept. If the concept understanding in mathematics learning is not achieved, then it will reduce the students' willingness in mathematics learning itself and they will consider mathematics as a difficult subject (Yahaya, 2010).

Overcoming this condition, it is necessary to find a solution to improve students' multiplication concept understanding. One of the alternatives that is possible to improve the multiplication concept understanding is using Jarimatika. Wulandani (2008) suggests that Jarimatika is one of the counting methods (the Multiply-To-AddLess operation) using fingers. The advantage of this Jarimatika method compared to the other methods is that Jarimatika emphasizes more on mastering the concept first and then on the fast way, so that the children master the knowledge thoroughly. In addition, this method is conveyed in a fun way, so that the children will feel happy and easy like a "learning excursion". Therefore, this Jarimatika method is expected to improve the multiplication ability that is being studied. With some benefits and advantages of the Jarimatika method above, the author understands that Jarimatika method is quite suitable to be given to improve the students' multiplication concept understanding.

Jarimatika will be more effective if it is supported by using media. In the learning process, it is better if we use the media as a tool to help the students in 
understanding mathematical concepts that are adapted to the material and learning methods (Sari, 2017). Learning media are anything that can be used to transmit the messages from the sender or teacher to recipients or students so that they can stimulate the thoughts, feelings, attentions, and interests and also the students' attention so that the learning process occurs (Sadiman, 2008). According to Arsyad (2011) in media selection, there are several criteria needs to be considered, including the objectives accordance, appropriately supporting the lessons content, practicality, and the skills of the teachers in using the media. Learning media is used to clarify the meaning of the messages conveyed by, so that the learning objectives can be achieved. Elementary students will be more interested in various things so that the students can be more focused and interested in following the learning process. Learning media is used to clarify the meaning of the messages delivered, so that the learning objectives can be (Lestari, et.al, 2018). Using an interesting media and methods, it will support the learning process in the classroom. The teachers can apply the appropriate learning media and methods with the mathematics material to be delivered. One of the appropriate media to be applied is Tapertis media. It makes the students easier to understand the multiplication numbers. By the help of the appropriate media in the learning process, it can help the students in learning and understanding the material (Wahyuningtyas \& Ladamay, 2016).

The research on concept understanding using media has been conducted by some experts. The research conducted by Wahyuningtyas and Ladamay (2016), on improving the multiplication concept understanding with Wayangmatika media, shows that the Wayangmatika media can improve the multiplication concept understanding. In addition, the research conducted by Pratiwi (2016), shows that the learning cycle of 5e assisted by Geogebra can improve the students' understanding of the mathematical concept. The similar research was also carried out by Komalasari and Pamungkas (2019), the result showed that the use of multisensorybased interactive multimedia improved the the understanding of multiplication and division concepts. based on some of the research above, the appropriate media is needed to improve the students' multiplication concept understanding. Tapertis media is one of the media that can be used. In Tapertis media, there are Tapertis calculator and Tapertis count for students practicing.

Realizing the importance of the appropriate learning media in mathematics learning, the researcher and the 4 graders' teacher agreed to choose Tapertis media as a learning media of multiplication learning. The aim of this research was to prove the effectiveness of using the Jarimatika method with Tapertis media on the 4 graders' multiplication concept understanding.

\section{METHOD}

\section{Type of Research}

The type of this research is an experimental research with a quantitative approach. The research design used an intact-Group Comparison type of preexperimental design, which is a variable research by deviding two groups, namely the experimental group and control group (Sugiyono, 2017). This design is one of the research designs that are included in the type of pre-experimental research with 2 (two) times observations, namely before the experiment called the pre-test and after the experiment called the post-test. The research location is in State Elementary School of Candigaron 03, Sumowono District. 


\section{Population and Sample}

The research population was all students of State Elementary School of Candigaron 03. The research sample was 17 students of 4 graders. The sampling technique used purposive sampling technique. Purposively the 4 graders was taken as the sample with the criteria that the students were still learning the multiplication concept understanding, the students were in a class whose the students' abilities were heterogeneous, not a superior or accelerated classes, and students had never received learning using the Jarimatika method and Tapertis media. According to the research design, this research divided the class into 2 groups, namely the experimental and control class. The experimental class consisted of 9 students. The control class consisted of 8 students.

\section{Data Collections and Analysis Techniques}

Data collection techniques are tests and observations. The tests used were the pre-test and post-test at the end of the lesson, to determine the students' multiplication concept understanding. The observation technique was carried out by observing the activities of the teacher and the students in the learning process using the observation sheets. Prior to the research, a prerequisite test was conducted, namely expert validation of the media, regarding the physical aspects of the media, the illustrations of pictures and sounds and also guidelines for using the media. If the expert validation gets a very good result, therefore Tapertis media can be used for the research. After the expert validation, a prerequisite test result of the research was carried out, namely testing the validity, reliability, normality, and homogeneity of the data. The validity test results of the research showed the number of 0.506 , it can be said that the data were valid. Reliability test results showed the number of 0.599 , it can be said that the data were reliable. The results of the normality test showed a significance level of $>0.05$ ( 0.625 for the experimental class and 0.954 for the control class), therefore it can be said that the data were normal. The homogeneity test results showed a significance level $<0.05$, so the data were homogeneous. After the data were valid, reliable, normal, and homogeneous, the data analysis carried out after the research was paired sample T-Test, linear regression test and also learning completeness.

\section{RESULTS AND DISCUSSION Expert Validity}

The summary of the data results of the Tapertis media validation are as follows.

Table 1. The summary of Tapertis media expert validity results

\begin{tabular}{llccc}
\hline \multirow{2}{*}{ No } & Sub Indicator & \multicolumn{3}{c}{ Total Validation Results Value } \\
& & Validator $\mathbf{1}$ & Validator 2 & Validator 3 \\
\hline 1 & Physical Media & 11 & 11 & 12 \\
2 & Pictures and Sounds Illustrations & 26 & 25 & 24 \\
3 & Guidelines for use & 20 & 20 & 20 \\
\hline Total & $\mathbf{5 7}$ & $\mathbf{5 6}$ & $\mathbf{5 6}$ \\
\hline Average & \multicolumn{3}{c}{ Very Good } \\
\hline Criteria & \multicolumn{3}{c}{} \\
\hline
\end{tabular}

Based on the data of the expert validity results, the Tapertis media obtained a final score of 56.33 with very good criteria. Tapertis media contains Tapertis calculator and Tapertis count to measure how much the students are able to understand the 
multiplication concept. When Tapertis media combined with the Jarimatika method, it will make the students easier to calculate the multiplication. Tapertis media also contains audio/sound which makes the students do not feel bores with the learning process, especially in mathematics subjects on multiplication material. By using media in the learning process can improve the students understanding and getting the information (Arsyad, 2011). Learning using Tapertis, it makes the students do practicing in multiplication over and over. This proves that the ability to count which is done continuously can improve the students' multiplication concept understanding. In this case, the teacher provides the exercises continuously in order to improve the students' multiplication concept understanding.

\section{The Effectiveness of the Jarimatika Method with the Tapertis Media on the Multiplication Concept Understanding}

In order to determine the effectiveness of the learning process between the control and experimental classes, it can be done the paired sample T-Test, average difference test (T-Test), regression test, and the learning completeness.

\section{Paired Sample T-Test}

The results of the paired sample t-test using SPSS 25.0 are in Table 2 below.

Table 2. Results of the Paired Sample T-Test

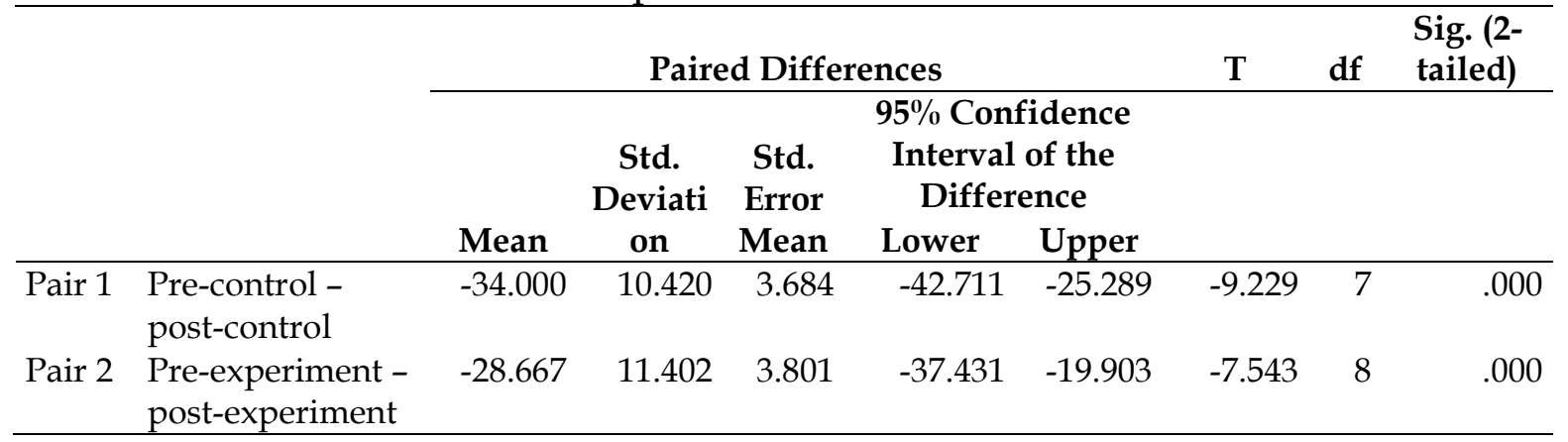

Based on Table 2, the significance level of $<0 . .05$ is $0.00<0.05$, therefore $\mathrm{Ha}$ is accepted. So, it can be concluded that there are differences in values before learning process and after learning process. It can be said that there are differences in values before and after learning process between control class and experimental class. Tapertis media with Jarimatika method is very helpful for the students in multiplication concept understanding. The results of the research are also supported by the research conducted by Nasution \& Surya (2015). The results showed that the application of Jarimatika technique can improve the ability to operate the multiplication numbers. This was also expressed by the research of Ahmadi \& Weijun (2014), states that the students have the higher significantly ability to count numeracy using Jarimatika during the post-test than in the pre-test. The application of Jarimatika was also confirmed by Wulandari (2008) who states that Jarimatika is a way of counting (multiplying minus operations) using the fingers. Jarimatika is a simple and fun way to teach the basic arithmetic to the children according to the rules. Jarimatika method does not eliminate the concept of mathematical operations, but the counting process can be done easier and faster (Husna, 2017). Jarimatika is a way of mathematics calculating using fingers as the tools (Prasetyono, 2009). The use of these tools is in line with the use of teaching aids so that the abstract concepts in mathematics appear concrete in the presence of the real objects. 


\section{After Learning Research Data Results (T-Test Results)}

The following are the results of the T-Test that was carried out on the students' mathematical value data by applying Tapertis media. In short, the results of the TTest are presented in Table 3.

Table 3. Results of the T-Test

\begin{tabular}{|c|c|c|c|c|c|c|c|c|c|c|}
\hline & & \multicolumn{4}{|c|}{$\begin{array}{c}\text { Levene's Test } \\
\text { for Equality } \\
\text { of Variances }\end{array}$} & \multicolumn{5}{|c|}{ t-test for Equality of Means } \\
\hline & & \multirow[b]{2}{*}{ F } & \multirow[b]{2}{*}{ Sig. } & \multirow[b]{2}{*}{$T$} & \multirow[b]{2}{*}{ Df } & \multirow{2}{*}{$\begin{array}{l}\text { Sig. (2- } \\
\text { tailed) }\end{array}$} & \multirow{2}{*}{$\begin{array}{l}\text { Mean } \\
\text { Dif. }\end{array}$} & \multirow{2}{*}{$\begin{array}{l}\text { Std. } \\
\text { Error } \\
\text { Dif. }\end{array}$} & \multicolumn{2}{|c|}{$\begin{array}{l}95 \% \text { Confidence } \\
\text { Interval of the } \\
\text { Difference }\end{array}$} \\
\hline & & & & & & & & & Lower & Upper \\
\hline Pre-test & $\begin{array}{l}\text { Equal variances assumed } \\
\text { Equal variances not assumed }\end{array}$ & .545 & .472 & $\begin{array}{l}-2.428 \\
-2.411\end{array}$ & $\begin{array}{r}15 \\
14.213\end{array}$ & $\begin{array}{l}.028 \\
.030\end{array}$ & $\begin{array}{l}-13.097 \\
-13.097\end{array}$ & $\begin{array}{l}5.394 \\
5.432\end{array}$ & $\begin{array}{l}-24.594 \\
-24.730\end{array}$ & $\begin{array}{l}-1.600 \\
-1.464\end{array}$ \\
\hline Post-test & $\begin{array}{l}\text { Equal variances assumed } \\
\text { Equal variances not assumed }\end{array}$ & 1.456 & .246 & $\begin{array}{l}-2.709 \\
-2.651\end{array}$ & $\begin{array}{r}15 \\
12.358\end{array}$ & $\begin{array}{l}.016 \\
.021\end{array}$ & $\begin{array}{l}-7.764 \\
-7.764\end{array}$ & $\begin{array}{l}2.866 \\
2.928\end{array}$ & $\begin{array}{l}-13.872 \\
-14.124\end{array}$ & $\begin{array}{l}-1.656 \\
-1.404\end{array}$ \\
\hline
\end{tabular}

Based on Table 3, it can be seen that the 2-way (t-tailed) significance value of $<$ $0.05(0.028<0.05,0.030<0.05,0.016<0.05,0.021<0.05)$. Therefore, it can be concluded that there are differences between the control and experimental groups. The average value of the multiplication concept understanding in the experimental class was also higher than the control class. The results of this research are supported by research conducted by Elita (2012). The results showed that the Jarimatika method was effective in improving the students' low ability in multiplication. the students' multiplication ability improved after using the Jarimatika method. Zulkardi (2010) states that "mathematics subject emphasizes the concept understanding, meaning that in mathematics learning, students must understand about the mathematical concept first in order to solve the problems and be able to apply this learning in a real life (Herawati, 2010). The use of media creatively can facilitate and improve the the learning efficiency so that the learning objectives can be achieved (Kurniawati \& Nita, 2018).

\section{Regression Test}

The results showed that there was an influence between the use of Tapertis media on students' multiplication concept understanding. This can be seen in Table 4 below.

Table 4. Simple Linear Regression Test

\begin{tabular}{|c|c|c|c|c|c|c|c|}
\hline \multicolumn{8}{|c|}{ Coefficients $^{a}$} \\
\hline & & $\begin{array}{r}\text { Unstar } \\
\text { Coef }\end{array}$ & $\begin{array}{l}\text { ardized } \\
\text { cients }\end{array}$ & $\begin{array}{l}\text { Standardizec } \\
\text { Coefficients }\end{array}$ & & & \\
\hline \multicolumn{2}{|c|}{ Model } & B & Std. Error & Beta & & $\mathrm{t}$ & Sig. \\
\hline 1 & (Constant) & 67.320 & 6.307 & & & 10.675 & .000 \\
\hline & Pre-test & .278 & .122 & & .506 & 2.272 & .038 \\
\hline
\end{tabular}

a. Dependent Variable: post-test

Based on Table 4, it can be seen that the significance value of multiplication concept understanding is 0,038 where this value is less than 0,05 , therefore the hypothesis is accepted. So that there is an effect of using Tapertis media on the students' multiplication concept understanding. Students' motivation in learning multiplication improves because of the form of Tapertis media which resembles educational games. Media is a graphic tool and graphic photos to capture, process or reconstruct visual or verbal information (Sukirman, 2015). By using interactive 
media, students are more enthusiastic and motivated in paying attention to the learning material (Komalasari \& Pamungkas, 2019). The students have the urge to keep practicing. This can be seen from the students' enthusiasm during multiplication learning, students who have high motivation to work on the exercises on the media. Learning media is a tool that can help the teaching and learning process and also uses to clarify the meaning of the messages conveyed, therefore it can be better and perfectly achieve the learning objectives (Kustandi \& Sutjipto, 2011). Learning media can help the students to understand the difficult material easily including in understanding the abstract concept to be more concrete (Novitasari, 2016).

\section{The Value of Multiplication Concept Understanding}

The summary of the value data of the students' multiplication concept understanding is in Table 5 below.

Table 5. The Summary of the Multiplication Concept Understanding Value

\begin{tabular}{cccccc}
\hline Classes & $\begin{array}{c}\text { Average } \\
\text { Value }\end{array}$ & $\begin{array}{c}\text { Students } \\
\text { Amount }\end{array}$ & Complete & Incomplete & $\begin{array}{c}\text { Completeness } \\
\text { Percentage }\end{array}$ \\
\hline Experiment & 84,89 & 9 & 9 & 0 & $100 \%$ \\
\hline Control & 77.12 & 8 & 7 & 1 & $87.5 \%$
\end{tabular}

The data of the multiplication concept understanding value, the average value of the experimental class was as much as 84.89 , with the classical completeness average up to $100 \%$ in the control class, the average value was 77.12 , with the classical completeness average reaching up to only $87.5 \%$. The concept understanding percentage of the experimental class was higher than the control class $(100>87.5)$. It shows that the application of Tapertis media is effective in improving the elementary students' multiplication concept understanding. Concept understanding is an ability that expects the students to be able to understand the known concepts, situations, and the facts, and also can be explained by their own words according to their knowledge, without changing the meaning (Purwanto, 2008). The students are said to understand a concept or understood about the given concept in the learning process if the students are able to present or explain the concept, they have gotten using their own words, not just memorizing (Ginanjar \& Kusmawati, 2016). The concept understanding in mathematics learning is one of the skills or abilities to understand and explain the situations or actions of the class or category, which has the common characteristics known by in mathematics (Rahayu, et al., 2018). This is in line with the research of (Febriani, et al., 2019) states that the ability of the mathematics concept understanding is the students' ability to convey or describe and explain from the language, by their own language and also be able to apply the concept to a problem, then be able to link between a concept to another. The students' ability in concept understanding is good if they can show the indicators in learning. Arikunto (2013) describes the indicators in realm of understanding including the maintaining, differentiating, explaining, expanding, concluding, generalizing, giving examples, rewriting, and estimating. The concept understanding is very important, because by mastering the concept will make the students easier in learning the lessons (Febriyanto, et al., 2018). 


\section{CONCLUSION}

The results showed that Jarimatika with Tapertis media has effectiveness in improving the grade 4 of elementary school students' concept understanding. The paired sample $t$-test results showed the significance level of $<0.05$ was $0.00<0.05$, therefore $\mathrm{Ha}$ is accepted. The t-test results showed that the average value of the control class learning and significance level of $<0.05$, therefore $\mathrm{Ha}$ is accepted. The regression test results showed that the significance value of the concept understanding as much as 0.038 where this value is less than 0.05 , therefore the hypothesis is accepted. The data of multiplication concept understanding value also showed that the experimental class is greater than the control class. The data analysis results showed that Jarimatika with Tapertis media has effectiveness in improving the students' multiplication concept understanding.

\section{RECOMMENDATION}

The recommendation that the authors expect from this research are: (1) teachers are more creative in designing the learning media so that the learning process becomes more enjoyable, (2) Tapertis media needs to be developed even better, with the addition of story questions and also problem solving in daily life.

\section{ACKNOWLEDGMENT}

This research can be completed by the help of many people. Therefore, the researcher expressed the gratitude and appreciation to those who have helped the completion of this research. The researcher would like to thank all who have helped during the research completion process, including: (1) The Ministry of Research, Technology and Higher Education, that has given the researcher the opportunity to get PDP grants, (2) The Chancellor of Ngudi Waluyo University, who has provided the guidance in writing this research, (3) The Research Institute and Community Service of Ngudi Waluyo University, that has provided the opportunity and guidance, (4) The Head of Research Program of Ngudi Waluyo University who has provided encouragement and spirit, (5) The Lecturers of Ngudi Waluyo University, who have given the encouragement and inspiration, also (6) All family of the State Elementary School of Candigaron 03 who have provided the time and space for this research. This research run smoothly because it has received a grant from the Ministry of Research, Technology and Higher Education in accordance with contract number 015/KTR-PENELITIAN/LPPM/UNW/III/2020 as well as the Letter of Assignment number 047/ST-Pen/LPPM/UNW/III/2020. Hopefully the results of this research are useful and contributed to the science development.

\section{REFERENCES}

Ahmadi, F. \& Weijun W. (2014). The Effect of "jarimatika" Multimedia in Counting Ability of Children. Information and Knowledge Management. 4(6), 40-47.

Arsyad, A. (2011). Media Pembelajaran. Jakarta: PT Raja Grafindo Persada.

Elita, S. (2012). Efektifitas Metode Jarimatika Dalam Meningkatkan Kemampuan Perkalian Bagi Anak Kesulitan Belajar. Jurnal Ilmiah Pendidikan Khusus. 1(1), 2334.

Febriani, P., Widada, W., \& Herawaty, D. (2019). Pengaruh Pembelajaran Matematika Realistik Berbasis Etnomatematika Terhadap Kemampuan 
Pemahaman Konsep Matematika Siswa SMA Kota Bengkulu. Jurnal Pendidikan Matematika Raflesia, 04(2), 120-135.

Febriyanto, B., Haryanti, Y.D. \& Komalasari, O. (2018). Peningkatan Pemahaman Konsep Matematis Melalui Penggunaan Media Kantong Bergambar Pada Materi Perkalian Bilangan Di Kelas II Sekolah Dasar, Jurnal Cakrawala Pendas, $4(2), 32-44$.

Ginanjar, G. \& Kusmawati, L. (2016). Peningkatan Kemampuan Pemahaman Konsep Perkalian Melalui Pendekatan Pembelajaran Konstruktivisme Pembelajaran Matematika Di Kelas 3 SDN Cibaduyut 4, Didaktik: Jurnal Pendidikan Guru Sekolah Dasar, 1 (2): 262-271.

Herawati, O., D., P. (2010). Pengaruh Pembelajaran Problem Posing Terhadap Kemampuan Pemahaman Konsep Matematika Siswa Kelas XI IPA SMA N 9 Palembang. Jurnal Pendidikan Matematika. 4(1): 70-80.

Heruman. 2007. Model Pembelajaran Matematika di Sekolah Dasar. Bandung: PT Remaja Rosdakarya.

Husna, A. (2017). Pelatihan Penggunaan Metode Jarimatika Untuk Menanamkan Konsep Cara Mudah Menghitung Perkalian Pada Siswa Sekolah Dasar RW. 01 Kelurahan Kibing, Minda Baharu, 1(1), 19-24.

Komalasari, M.D. \& Pamungkas, B. (2019). Meningkatkan Pemahaman Konsep Perkalian Dan Pembagian Menggunakan Multimedia Interaktif Berbasis Multisensoris Pada Siswa Berkesulitan Belajar, Elementary School, 6(1), 50-58.

Kurniawati, I.D. \& Nita, S. (2018). Media Pembelajaran Berbasis Multimedia Interaktif untuk Meningkatkan Pemahaman Konsep Mahasiswa, DoubleClick: Journal of Computer and Information Technology, 1(2), 68-75.

Kustandi, C \& Sutjipto, B. (2011). Media Pembelajaran. Bogor: Ghalia Indonesia.

Lestari, S., Sulianto, J. \& Purnamasari, V. (2018). Pengembangan Media Dora Jarimatika Pada Materi Perkalian Bilangan Bulat Terhadap Pemahaman Konsep Siswa Kelas IV SDN Jimbaran 02 Pati. SENDIKA [Seminar Nasional Pendidikan] 2018, 657-668.

Mawaddah, S. \& Maryanti, R. (2016). Kemampuan Pemahaman Konsep Matematis Siswa Smp Dalam Pembelajaran Menggunakan Model Penemuan Terbimbing (Discovery Learning), EDU-MAT Jurnal Pendidikan Matematika, 4(1), 76 - 85.

Mei, M.F, Seto, S.B. \& Wondo, M.T.S. (2020). Pembelajaran Kontekstual Melalui Permainan Kelereng Pada Siswa Kelas III SD Untuk Meningkatkan Pemahaman Konsep Perkalian, JUPIKA: Jurnal Pendidikan Matematika Universitas Flores, 3(2), 61-70.

Nasution, T.K \& Surya, E. (2015). Penerapan Teknik Jarimatika Dalam Upaya Meningkatkan Kemampuan Operasi Hitung Perkalian Bilangan. Edumatica, 5 (2), 48-58.

Novitasari, D. (2016). Pengaruh Penggunaan Multimedia Interaktif Terhadap Kemampuan Pemahaman Konsep Matematis Siswa, Fibonacci Jurnal Pendidikan Matematika \& Matematika, 2(2), 8-18.

Prasetyono, Dwi Sunar. (2009). Pintar Jarimatika. Yogjakarta: Diva Press. 
Pratiwi, D.D. (2016). Pembelajaran Learning Cycle 5e berbantuan Geogebra terhadap Kemampuan Pemahaman Konsep Matematis, Al-Jabar: Jurnal Pendidikan Matematika, 7(2), 191-202.

Purwanti, R.D., Pratiwi, D.D. \& Rinaldi, A. (2016). Pengaruh Pembelajaran Berbatuan Geogebra terhadap Pemahaman Konsep Matematis ditinjau dari Gaya Kognitif, Al-Jabar: Jurnal Pendidikan Matematika, 7(1), 115-122.

Purwanto. (2008). Prinsip-Prinsip dan Teknik Evaluasi Pembelajaran. Bandung: Remaja Rosdakarya.

Rahayu, W.D., Rohaeti, E.E., \& Yuliani, A. (2018). Analisis Kemampuan Pemahaman Matematik Siswa Mts di Kabupaten Bandung Barat. Jurnal Math Educator Nusantara (JMEN), 4(1): 79-86.

Sadiman, A.S. 2008. Media Pendidikan. Jakarta: Rajawali Pres.

Sari, P. (2017). Pemahaman Konsep Matematika Siswa Pada Materi Besar Sudut Melalui Pendekatan PMRI, Jurnal Gantang, 2 (1), 41-50.

Sugiyono. (2017). Metode Penelitian Kombinasi (Mixed Methods). Bandung: Alfabeta.

Arikunto, S. (2013). Dasar-Dasar Evaluasi Pendidikan. Jakarta: Bumi Aksara.

Sukirman. (2015). Pengembangan Media Pembelajaran. Yogyakarta: PT. Pustaka Insan Madani.

Wahyuningtyas, D.T. \& Ladamay. I. (2016). Meningkatkan Pemahaman Konsep Perkalian dan Pembagian Bilangan Bulat Menggunakan Media Wayangmatika. Pancaran, 5 (3), 51-60.

Wulandani, S.P. (2008). Jarimatika Perkalian dan Pembagian. Jakarta: Kawan Pustaka.

Yahaya, A. (2010). Kepentingan Kepahaman Konsep dalam Matematik. Malaysia: Universiti Teknologi Malaysia.

Zulal, S, Yenmez, A.A. \& Erbas, A.K. (2015). Relational Understanding Of The Derivative Concept Through Mathematical Modeling: A Case Study, Eurasia journal of mathematics, science $\mathcal{E}$ technology education, 11(1), 177-188.

Zulkardi \& Ilma, R. (2010). Pengembangan Blog Support untuk Membantu Siswa dan Guru Matematika Indonesia Belajar Pendidikan Matematika Realistik Indonesia (PMRI). JIPP Balitbang. 